\title{
Implementasi Nilai-Nilai Multikultural Di Pesantren Tebuireng
}

Nahatuz Zamani ${ }^{1}$, Iva Inayatul Ilahiyah ${ }^{2}$

1,2 Universitas Hasyim Asy'ari Jombang, Indonesia

\begin{tabular}{l}
\hline Article Info \\
\hline Article history: \\
Received, Januari 5, 2019 \\
Accepted, Maret 3, 2019 \\
\hline
\end{tabular}

\section{Keywords:}

Multicultural Values

Tebuireng Boarding School Pesantren

\begin{abstract}
The research was conducted aimed at knowing the implementation of multicultural values in the Tebuireng boarding school. The research method used is qualitative descriptive research with place settings in the Tebuireng boarding school. The data collection technique is by interview and documentation, the analysis used is inductive analysis techniques. The results of the study show that the Tebuireng Islamic boarding school is a boarding school that applies multicultural values. The planting of multicultural values to build a multicultural attitude in the Tebuireng Islamic boarding school is widely taught through daily examples of pesantren leaders. Formal teaching is taught in formal education units obtained at school by reviewing the work of the treatises of Ahlussunnah wal Jamaah and in the citizenship lesson Tasamuh is one of the five basic values of the Tebuireng Islamic boarding school which have the same character as multicultural values. The implementation of multicultural values at the Tebuireng Islamic boarding school is applied daily to santri, spelled out since the placement of santri rooms and customs living together from a variety of different backgrounds, pesantren activities attended by all santri, the study of Hadrotussyaikh Hasyim Asy'ari Risalah Ahlussunnah Wal Jamaah which contains about the teachings of tolerance, fairness, moderation and in formal education of multicultural value planting through lessons in Citizenship Education (PKN) and Pancasila Morals. Kiai in a pesantren has a very important role, the figure of KH Salahuddin Wahid as a Tebuireng boarding school caregiver has character, model, style, which emphasizes the teachings of rahmatal lilalamin so that it dominates the character of the current Tebuireng boarding school.
\end{abstract}

This is an open access article under the CC BY-SA license.

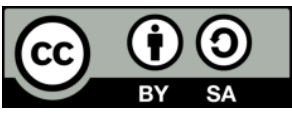

\section{Corresponding Author:}

Nazhatuz Zamani

Pendidikan Agama Islam, Fakultas Agama Islam, Universitas Hasyim Asy’ari Jombang Jawa Timur e-mail (nazhazaa@gmail.com)

Iva Inayatul Ilahiyah

Dosen Pendidikan Agama Islam, Fakultas Agama Islam, Universitas Hasyim Asy’ari

\section{PENDAHULUAN}

Indonesia, negara kepulauan terbesar di dunia dengan kekayaan ragam hayati, secara geografis Indonesia memiliki lebih dari 17.500 pulau besar dan kecil, terhitung dari Sabang sampai Merauke. Luas wilayah Indonesia membawa pengaruh pada keragam budaya yang berbeda Indonesia, baik secara horizontal maupun vertikal. Secara horizontal perbedaan meliputi kesatuan sosial seperti suku, bangsa, bahasa, adat istiadat, dan agama, secara vertikal meliputi perbedaan lapisan atas dan bawah, sosial, politik, ekonomi maupun budaya. Luas wilayah secara geografis inilah yang membawa Indonesai pada keanekaragaman kultur, baik secara horizontal yang meliputi perbedaan kesatuan sosial seperti suku, bangsa, bahasa, adat istiadat, dan agama, maupun secara vertikal yang meliputi perbedaan lapisan atas dan bawah, sosial, politik, ekonomi, maupun budaya. 
Keragaman pada hakikatnya bukan hanya membawa pada kebaikan, tidak sedikit terjadi problematika yang terjadi diantara kita dari pertengkaran antar suku, perbedaan budaya, maupun perbedaan politik. Beberapa waktu terakhir banyak kita dengar bersama kabar buruk pertikakian yang disebabkan beda pendapat beda pilihan.

Bagi Ahmad Baedowi (2012 : 172) perbedaan bukan hanya yang bersifat fisik seperti ras, agama, bahasa, gender, tetapi lebih pada perilaku, sifat, watak, bahkan karakter seseorang atau yang meliputi nilai (values) dan tipologi personal sesorang. Multikultural dipahami sebagai sikap menerima dan terbuka atas perbedaan. Pendidikan multikultural banyak diwacanakan sebagai salah satu treatment untuk penanaman sikap toleransi pada individu sejak usia dini. Pendidikan bagi Assegaf (2011 : 220) bukan hanya bersifat memindahkan pengetahuan (transfer of knowlage) tetapi pendidikan memiliki makna sebagai proses transfer sikap atau nilai (transfer of values).

Nilai-nilai multikultural dapat diwujudkan dimanapun dan kapanpun. Seperti halnya lingkungan sekolah, lingkungan keluarga, lingkungan masyarakat dan lingkungan pesantren. Pesantren merupakan lingkungan yang strategis sebagai media implementasi nilai-nilai multikultural, yakni dengan mengamalkan sikap saling menyayangi, menghargai, menghormati kepada beragam individu disetiap saat. Seimbang dengan firman Allah dalam Al Quran

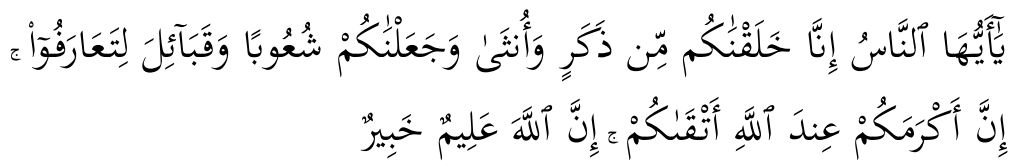

Hai manusia, sesungguhnya Kami menciptakan kamu dari seorang laki-laki dan seorang perempuan dan menjadikan kamu berbangsa-bangsa dan bersuku-suku supaya kamu saling kenal-mengenal. Sesungguhnya orang yang paling mulia diantara kamu disisi Allah ialah orang yang paling takwa diantara kamu. Sesungguhnya Allah Maha Mengetahui lagi Maha Mengenal. (Al Hujurat : 13)

Pesantren sebagai lembaga pendidikan tertua di Indonesia mejadi salah satu lembaga pendidikan yang dapat memenuhi kebutuhan individu. Bukan hanya sebagai lembaga yang mengajarkan ilmu bidang agama (spiritual) tetapi pesantren saat ini menyediakan lembaga pendidikan formal sehingga tidak menjadi lembaga pendidikan yang terbelakang, terlebih pesantren memilki sifat majmuk dimana penduduk mayoritasnya adalah santri yang memiliki keragaman perbedaan baik bersifat horizontal maupun vertikal mendukung implemnatasi nilai-nilai multikultural. Zamarkhasyari (2011 : 18) mengemukakan Pesantren secara etimologi berasal dari kata pe-santri-an yang dipahami sebagai tempat tinggal santri (asrama tempat santri belajar agama). pendapat lain mengemukakan pesantren adalah tempat berkumpul untuk belajar agama.

Dilansir dari website Tebuireng.online pada 3 april 2019 pesantren Tebuireng adalah salah satu persantren tua di Indonesia, yang didirikan oleh hadrotusyaikh Hasyim Asy'ari berswam istrinya Nyai Khodijah pada 25 Rabiul Awal 1317 bertepatan tanggal 3 Agustus 1899 M. Pesantren Tebuireng dapat dijadikan sebagai teladan dalam hal implementasi nilai nilai multikultural. KH Salahuddin Wahid, pengasuh pesantren Tebuireng saat ini merupakan sosok kiai yang dikenal dengan sikap jujur dan tasammuh. KH Salahuddin Wahid juga merumuskan lima nilai dasar pesantren Tebuireng sejak ia menjadi penagsuh pesantren Tebuireng. Lima nilai dasar ini diambil dari pemikiran atau ajaran hadrotussyaik Hasyim Asy'ari, lima diantaranya adalah 1. ikhlas, 2. jujur, 3. kerja keras, 4. tanggung jawab, dan 5. tasamuh atau sikap lapang hati, peduli, toleran, menghargai perbedaan, anti kekerasan dan menghargai hak orang lain. Nilai tasamuh dalam pesantren Tebuireng sesuai dengan nilai-nilai multicultural.

Fokus Penelitian Berdasarkan penjelasan yang dpaparkan diatas, mengahsilkan fokus masalah, diantaranya adalah : (1) pa saja nilai-nilai multikultural di pesantren Tebuireng Jombang ? (2) Bagaimana implementasi nilai-nilai multikultural di pesantren Tebuireng?

Secara umum penilitain ini bertujuan untuk mendapatkan gambaran secara subyekif mengenai implemnetasi nilai-nilai multikultural dipesantren Tebuireng : Untuk mengetahui nilai-nilai multikultural di pesantren Tebuireng, Untuk mengetahui implementasi nilai-nilai multikultural di pesantren Tebuireng. Secara etimologi Andre ata (2009 : 14) dkk memaknai multikultural memiliki makna keberagaman budaya. Multikutural berasal dari dua suku kata, multi artinya banyak atau beragam dan kultural budaya atau kebudayaan. Dalam buku multikultikuturalisme, multikultural dipahami sebagai bentuk sikap multikulturalisme atau sikap terbuka atas perbedaan.[f1] Pada dasarnya semua bangsa yang berdiri di dunia bersifat multikultural. Adanya masyarakat multikultural memberikan nilai tambah bagi bangsa tersebut. Keragaman ras, etnis, suku, ataupun agama menjadi karakteristik tersendiri, sebagaimana bangsa Indonesia yang unik dan rumit karena kemajemukan suku bangsa, agama, bangsa, maupun ras. 
Masyarakat multikultural Indonesia adalah sebuah masyarakat yang berdasarkan pada ideologi multikulturalisme atau Bhinneka Tunggal Ika yang multikultural, yang melandasi corak struktur masyarakat Indonesia pada tingkat nasional dan lokal. Berkaca dari masyarakat multikultural bangsa Indonesia, kita akan mempelajari penyebab terbentuknya masyarakat multikultural.

M Mahrus (2017 : 4) mememaparkan konsep masyarakat multikultural sama dengan semboyan Bhinneka Tunggal Ika yang menggambarkan sebuah 'monumen' betapa bangsa yang mendiami wilayah dari Sabang sampai Merauke ini memang merupakan bangsa yang majemuk, plural, dan beragam. Majemuk artinya terdiri atas beberapa bagian yang merupakan kesatuan, plural artinya lebih dari satu, sedangkan beragam artinya berwarna-warni. Indonesia akan menjadi bangsa yang damai dan sejahtera apabila suku bangsa dan semua unsur kebudayaannya mau bertenggang rasa membentuk satu kesatuan.

Diungkapkan dalam buku Abdullah (2011 : 109) Bank mendefinisikan Pendidikan multikultural Banks sebagai sebuah kebijakan sosial yang didasarkan pada prinsip-prinsip pemeliharaan budaya dan saling memiliki rasa hormat antara seluruh kelompok budaya di dalam masyarakat. Pendidikan multikultural adalah pendidikan yang menghargai heterogenitas dan pluralitas, pendidikan yang menjunjung tinggi nilai kebudayaan, etnis, suku, dan agama serta menghargai dan menghormati keragaman budaya yang ada di dalam kehidupan masyarakat. Nilai-nilai multikultural terbalut dalam tiga karateristik pendidikan multikultural. Prinsip pertama adalah berprinsip pada demokrasi, kesetaraan dan keadilan. Kedua, berorientasi pada kemanusiaan, keberagaman, dan kedamaian. Ketiga, megembangkan sikap mengakui, menerima dan menghargai keragaman budaya.

Berprinsip pada karekter pendidikan multikultural yang pertama, nilai-nilai multikultural presperktif Islam meliputi demokrasi (al musyawarah), kesetaraan (al musawwah), dan adil (al adl). Al musyawarah memiliki arti musyawara, pertimbangan, dan nasehat, musyawarah merupakan landasan dalam berinteraksi bukan saja dalam lingkup politik tetapi musyawarah juga digunakan sebagai metode interaksi sosial untuk menghasilkan suatu keputusan bersama. Al musawwah berarti kesetaraan, bahwasannya manusia adalah bersaudara berasal dari satu ciptaan dan dan setara dihadapan Pencipta, meski memiliki keragaman perbedaan dan kepercayaan.

TABLE I. TABEL 1. KARAKTERISTIK MULTIKULTURAL DARI PERSPEKTIF BARAT DAN ISLAM

\begin{tabular}{|c|c|c|}
\hline Karateristik & $\begin{array}{c}\text { Nilai multikultural } \\
\text { prespektif Barat }\end{array}$ & $\begin{array}{c}\text { Nilai multikultural } \\
\text { berbasis Islam }\end{array}$ \\
\hline $\begin{array}{l}\text { Berprinsip } \\
\text { demokrasi, kesetaraan, } \\
\text { dan keadilan. } \\
\text { Berorientasi } \\
\text { kemanusiaan, } \\
\text { kebersamaan, } \\
\text { kedamaian }\end{array}$ & $\begin{array}{l}\text { Demokrasi, } \\
\text { kesetaraan, dan } \\
\text { keadilan } \\
\text { Kemanusiaan, } \\
\text { kebersamaan, dan } \\
\text { kedamaian }\end{array}$ & $\begin{array}{l}\text { Al-musyawarah, al } \\
\text { musawamah, dan } \\
\text { al-adl } \\
\text { Hablum min annas, } \\
\text { al ta'rif, al ta'awun, } \\
\text { dan alsalam }\end{array}$ \\
\hline $\begin{array}{l}\text { Membangunkan sikap } \\
\text { mengakuo, menghargai } \\
\text { dan menerima } \\
\text { keragaman. }\end{array}$ & $\begin{array}{l}\text { Toleransi, empati, } \\
\text { simpati, dan } \\
\text { solidaitas sosial. }\end{array}$ & $\begin{array}{l}\text { al-'afu, al-rahmah, } \\
\text { tasamuh, } \\
\text { tanawwn', } \\
\text { ta'addudiyat }\end{array}$ \\
\hline
\end{tabular}

Sumber : pendidikan islam multikultural di pesantren karya Abdullah Aly

Menurut Ismail (2002 : 25)Pesantren memiliki lingkungan yang heterogen, di mana seluruh santri yang berada dipesantren datang dari barbagai perbedaan ras, budaya, lapisan sosial masyarakat, bahkan dengan karakter individu yang beragam. Begitu pula dengan pola hidup di pesantren yang mengedepankan penanaman dan penerapan nilai-nilai agama saling menolong, toleransi, saling menghormati, saling berbagi. Hal tersebut senada dengan masyarakat multikultural.

Imron Arifin (2010 : 13) mengemukakan konsep pondok pesantren merupakan lembaga pendidikan islam yang terlaksana dengan sistem asrama dan kiai sebagai pusat utama pelaksanaan pembelajaran, serta masjid sebagai wahana pusat terselengaranya kegiatan pembelajaran. Awal berdirinya pesantren bermula dari masjid, para santri tinggal menyebar di desa-desa, dan saat tiba waktu mengaji bersama kiai para santri berdatangan untuk mengikutinya.

perbedaan pendapat mengenai sejarah pesantren,diungkapkan oleh Abdullah (2011 : 109) menurut Steenbrink lemabaga pendidikan pesantren di adopsi dari India. Dengan alasan secara terminologi beberapa istilah yang digunakan dipesantren seperti kata mengaji, dan pondok bukan berasal dari bahasa Arab, melainkan berasal dari India. Steenbrink juga menggunakan sejarah sebagai alasan, sistem pendidikan pesantren telah teraplikasikan secara umum dalam pengajaran Hindu di Jawa, namun ketika islam masuk dan tersebar di tanah Jawa sistem dan istilah istilah-istilah pesantren di adopsi oleh Islam. Sedangkan Bruinessen mengemukakan pendapat pesantren berasal dari Arab, ia mengemukakan kitab kuning yang diselenggarakan di Pesantren menggunakan bahasa Arab. Begitu pula dengan pola pendidikan yang terapkan di Pesantren yang menterupai pendidikan madrasah dan zawiyah di Timur Tengah. Zawiyah 
merupakan peneyelnggaraan pendidikan di sudut masjid dengan membentuk lingkaran, sedangkan madrasah merupakan sistem pendidikan di luar masjid, kedua tempat tersebut bertujuan membentuk peserta didik mencari calon ulama.

Sedangkan dalam catatan Nurcholis Majid terdapat empat istilah Jawa yang dominan digunakan di pesantren, yakni : santri, berasal dari bahasa jawa cantrik yang berarti seseorang selalu mengikuti guru kemanapun ia pergi. Kata kedua adalah kiai, kata kiai juga berasal dari bahasa jawa yang seringkali digunakan untuk memanggil kakek, kata kiai ini mengandung pengertian rasa penghormatan terhadap orang tua. Ketiga adalah kata ngaji, yang berasal dari kata aji yang berarti terhormat dan mahal, kata ngaji biasa disambungkan dengan kata kitab yang berarti santri mempelajari kitab dalam bahasa Arab, yang kemudian kitab tersebut dikaji bersama dengan kiai sebagai pembaca atau pemberi makna dan ditulis oleh santri. Kegitan tersebut terdengar familiar dengan sebutan njenggoti yang berasal dari bahasa jawa, istilah keempat ini digunakan karena catatan mereka menggantung pada kata-kata yang di maknai oleh kiai sehingga seperti jenggot.

Ali Maksum (2015 : 17) Pesantren Tebuireng merupakan salah satu pesantren tua di Indonesia, pada tanggal 25 Rabiul Awal 1317 bertepatan tanggal 3 Agustus 1899 M, Hadrotusyekh Hasyim Asy'ari mendirikan bangunan kecil dari anyaman bambu berukuran 6x8 meter, bangunan tersebut bibagi menjadi dua bagian yaitu bagian depan digunakan sebagai musolah atau tempat salat dan bagian yang belakang digunakan sebagai tempat tinggal hadrotusyekh Hasyim Asy'ari berserta istri Nyai Khodijah. Pesantren Tebuierng pada mulanya mengunakan sistem sorogan atau seornag santri membaca kitab kuning dihadapan guru, dan metode watonan atau bandongan atau yang disebut juga dengan halaqoh yakni kiai membacakan kitan santri menyimak dan menuliskan makna. Pada tahun 1919 M peneyelengaraan sistem madrasah (klasikal) oleh Hadroutsyekh Hasyim Asy'ari dengan mendirikan madrasah madrasah Salafiyah Syafi'iyah, sistem pengajaran berjenjangan dalam dua tingkat yakni Shifir Awal dan Sifir Tsani.

Imron Arifin (2010 : 13) menjelaskan pesantren Tebuireng dipimpin oleh hadrotusyekh Hasyim berlangsung kurang lebih 48 tahun, tepatnya dari tahun 1899-1947. Dalam kurun waktu itu telah banyak peristiwa penting yang telah diukir olehnya. Pertama, dalam bidang pendidikan hadrotusyekh Hasyim Asy'ari berhasil mendidik sejumlah kecil santri yang terpilih sampai sempurna betul dalam menyelesaikan pelajarannya di Tebuireng dan kemudian mampu mendidirikan pesantren sendiri.

\section{METODE}

Penelitian implementasi nilai-nilai multikultural di pesantren Tebuireng merupakan penelitian deskriptif kualitatif, yakni dengan mengunggkapkan, menjelaskan dan menggambarkan implementasi nilai multikultural di pesantren Tebuireng yang bertujuan menbentuk karakter individu yang tasamuh. Menurut Emzir (2008 : 175) Penelitian deskriptif memberikan gambaran situasi dan kondisi sehingga memudahkan pembaca mengetahui situasi dan kondisi di lingkungan penelitian dengan memberikan pandangan atau pendapat responden yang berada di latar penelitian.

Pesantren Tebuireng menjadi obyek penelitian implementasi nilai-nilai multkultural, teknik pengumpulan data yang digunakan adalah dengan wawancara dan dokumentasi. Wawancara mendalam (indept interview) yang dilakukan menggunakan pedoman wawancara (interview guide), sementara dokumentasi digunakan sebagai informasi yang bersifat sekunder.

Menurut Sanapiah faisal (2001 : 34) Analisis data dalam penelitian ini yakni mengorganisasikan data ke dalam susunan-susunan guna menginterprestasikan data. Data dipilah sesuai dengan sajian data yang dibutuhkan untuk menghasilkan jawaban atas penelitian dan kemudian di simpulkan sesuai dengan masingmasing masalah dalam penelitian yang diteliti.

Burhan Bugin (2001 : 209) mengemukakan Teknik keabsahan data yang digunakan dalam penelitian ini adalah dengan pengecekan keabsahan data menggunakan triagulasi, Triangulasi dalam pengujian kredibilitas ini diartikan sebagai pengecekan data dari berbagai sumber dengan berbagai cara, dan berbagai waktu.

\section{HASIL DAN PEMBAHASAN}

Pesantren memiliki kesamaan dalam beberapa hal, di pesantren terdapat beragam kultur, bahasa, suku, dan juga pendapat, akan tetapi di pesantren terdapat khazanah ilmu sehingga dapat menjadi tempat yang damai diatas beragam perbedaan. Lukman, (30 Maret 2019) "Pengertian pesantren tentang multikultural menerima dari segala bentuk perbedaan dari agama islam maupun agama yang lain, jadi harus menerima segala perbedaan pendapat, baik secara teknis, teknis apapun harus secara kemanusiaan kita terima tetapi kita memiliki batasan tidak harus kita ikuti sebagai simbol kemanusiaan kita saling mengahargai sesama"

Sikap multikultural menjadi makanan pokok dalam kehidupan sosial terlebih dilingkungan yang bersifat majmuk. Pesantren merupakan suatu lingkungan yang majmuk teridri dari beragama perbedaan. Minahul (13 April 2019) "Sikap multikurtural bukanlah suatu hal yang harus di hindari, akan tetapi sikap multikurtural layaknya di gunakan pada keseharian kita bersama mengingat negara kita ini kan Bhineka 
Tunggal Ika maka sangat perlu sikap multikurtural dalam membangun kmunikasi dengan sesama dengan latar belakang keragaman perbedaan pesantren memiliki karakteristik yang sama dengan Indonesia yaitu terdiri dari ragam perbedaan budaya, bahasa terlebih pendapat"

Ananda (20 April 2019) "Kesadaran atas adanya perbedaan itu sangat penting dalam suatu komunikasi. Nah di pesantren itukan lingkungannya sudah majmuk, jadi secara tidak langsung akan terbawa lingkungan menjadi seseorang yang menerima perbedaan, tentunya tetap melalui proses kebiasaaan. Lingkungan di pesantren ini kita diajarkan banyak hal seperti li taarafu saling mengenal satu sama lain, ditambah dengan penanaman menjadi seorang yang baik melalui pengajaran maupun teladan langsung"

Nilai-nilai multikultural di pesantren Tebuireng meliputi nilai Al-Musyawarah (demokrasi), AlMusawah (kesetaraan), Al-Adl (Adil), Hablumminannnas (Hubungan dengan manusia), Al-Ta'aruf (saling mengenal), Al-Ta'awun (saling menolong), Assalam (kedamaian), Al-'afw (memberi maaf), al-rahmah (kasih sayang), tasamuh (toleransi), al-ta'addudiyat (pluralisme), al-tanawwn' (keragaman). Seimbang dengan nilai nilai multikultural prespektif islam, melalui sikap multikultural yang ditanamkan kepada santri-santri di Tebuireng dilaksanakan pada kegiatan sehari-harinya, hidup bersama orang yang belum ia kenal sebelumnya menjadi salah satu usaha li taarafu (saling mengenal), mengenal adalah langkah pertama saat hidup bersama, terlebih dengan orang-orang yang meimiliki perbedaan budaya, bahasa, adat istiadat.

Pesantren Tebuireng dapat dikatakan sebagai pesantren yang mengimplementasikan nilai multikultural. Di pesantren Tebuireng teraplikasikan nilai al-musyawarah atau demokrasi, dalam kegiatan organisasi yang berdiri di pesantren Tebuireng mayoritas menggunakan pola al-musyawarah atau demokrasi bukan hanya melalui organisasi tetapi juga terdapat kegiatan yang meliputi nilai al-musyawarah yaitu kegiatan basthul masail yang diselenggarakan di setiap kamar yang didampingi oleh pembina kamar masing-masing. Begitu pula dengan al-musawah atau kesetaraan dari hasil penelitian yang di dapatkan dari narasumber almusawah atau kesetaraan diterapkan oleh pesantren dalam menengakkan hukum atau aturan pesantren tidak melihat strata sosial. Kemudian penerapan $a l$-adl atau adil juga diterapkan sejak pendaftaran santri baru siapapun yang memnuhi syarat dan lulus ujian maka ia dapat masuk di pesantren Tebuireng, tidak memandang bulu.

Hidup dipesantren, bersama dengan orang-orang yang baru dikenal tentu bukan hal yang mudah tetapi lingkungan pesantren yang menanamkan sikap saling peduli menimbukan nilai hablumminannas membangun hubungan baik dengan manusia, dan terbangunlah nilai al-taawun atau rasa saling menolong, dikit demi sedikit terbangunlah sikap solidaritas sosial yang baik dengan membangun assalam atau kedamaiaan shingga sedikit sekali terjadi konflik yang disebabkan karena perbedaan kultur budaya, bahasa, bahkan watak atau karakter. Penanaman niali Al-'afw atau saling memberi maaf, al-rahmah saling kasih sayang, dan tasamuh atau toleransi mampu membuka diri atau pikiran santru menjadi seorang yang alta'addudiyat pluralisme diatas aI-tanawwn' atau keragaman perbedaan.

Penanaman nilai-nilai multikultural untuk membangun sikap multikultural di pesantren Tebuireng lebih banyak di ajarkan melalui teladan keseharian tokoh tokoh pesantren. Pengajaran secara formal di ajarkan di unit pendidikan formal di seluruh jenjang unit pendidikan pesantren Tebuireng. Pengajaran multikultural secara formal didapat disekolah dengan mengkaji kitab karya risalah ahlussunnah wal jamaah dan di pelajaran kewarganegaraan, sedangkan secara tidak formal didapatkan melalui teladan dan nasehat-nasehat dari kiai, ustad, dan guru guru

Pesantren Tebuireng memiliki lima nilai dasar pesantren yang dirumuskan oleh penagsuh pondok pesantren Tebuireng KH Salahuddin Wahid. Yang pertama adalah ikhlas, ke ikhlasan kita dalam mengerjakan sesuatu, ikhlas berarti bersih semata mengharap ridha Allah. Yang kedua, jujur seorang yang jujur akan merasakan buah kedamaian, tidak merasa takut, dan dapat hidup tenang. Yang ketiga, kerja keras berusa berjuang dengan sungguh sungguh dan gigih mencapai cita-cita. Keempat, tanggung jawab merupakan perilaku yang wajib dimiliki setiap personal santri dalam kehidupan sehari hari. Dan yang terakhir, tasamuh sikap lapang hati, keterbukaan pikiran, menghargai perbedaan, toleran dan peduli.

Implementasi nilai-nilai multikultural di pesantren Tebuireng diterapkan pada kegiatan sehari-hari santri. Bermula sejak santri mondok di pesantren Tebuireng penempatan tempatt tinggal (kamar/asrama) yang terdiri dari beragam daerah, pada kegiatan sekolah formal penerapan multikultural melalui pelajaran Pendidikan Kewarganegaraan (PKN) dan Moral Pancasila. Pada pelajaran tersebut santri menerima pendidikan multikultural dengan mengedepankan pelajaran kesadaran berbangsa dan negara, dan penanaman sikap-sikap moderat, berprilaku adil, saling menyayangi, menghormati dan menghargai sesamanya.

Demikian pula dalam kegiatan di pesantren, selain setiap hari bertatap muka, bersosialisai dengan orang yang berbeda beda, pengkajian kitab-kitab salaf yang diajarkan di pesantren dan diikuti oleh santri-santri. Kitab risalah Ahlussunnah Wal Jamaah merupakan kitab karya Hadrotussyaikh Hasyim Asy'ari yang didalamnya terdapat ajaran-ajaran ahlussunnah wal jamaah, dengan karateristik penanaman sikap sikap moderat, toleran, dan sikap adil.

Kiai memiliki peran sentral di lingkungan pesantren menjadi sosok teladan utama bangi santri santrinya, begitupula dengan Dr. Ir. KH Salahuddin Wahid sosok pengasuh yang terbuka, tasamuh menyalurkan energi positif kepada santri santrinya. 
Seto (27 April 2019)“Teladan dari sosok yai solah menerima segala golongan dari agama hindu, budha, kristen, yang mau silaturrahmi dari manapun juga dibuka lebar lebar, inilah Tebuireng membuka untuk semua golongan tapi ada filter-filter kalau-kalau ada yang masuk dengan maksud yang tidak sesuai seperti contoh mungkin berkunjung dengan kecenderungan untuk kampanye maka pesantren Tebuireng akan menolak tetapi kalau emang mau berkunjung dengan tujuan silaturrahmi maka akan diterima dengan baik. nah itulah yai solah merangkul semuanya. Yai solah membawa pengaruh besar terhadap santri, jadinya nanti santri melihat “yai ku rek sosok menerima semua perbedaan” jadi didalam jiwanya jadi enggak risih, misalnya punya temen dari agama kristen budha ayo gabung nih, jadi misalnya didiri santri ada rasa risih nih mereka jadi keinget dulu yaiku menerima semua yaudah ayo gabung. Misal nanti dirumah jadi tokoh misal ada silaturrahim lintas agama jadi gak kaget keinget oh ya dulu yaiku menerima semuanya. Seperti hotman paris meski bukan islam kemaren disambut juga oleh santri dengan baik, nah itukan karena yai solah terbuka maka santri santrinya ikut terbuka. Selain yai solah ada yai ta'in beliau juga sosok yang terbuka meskipun tidak se luwes yai solah. Yai tain itu terbuka tapi masih menjaga jarak, menjaga jarak ini ada maksud menajaga agama juga. Seperti contoh kemaren beliau mengusulkan jangan ke candi-candi karena kalau nanti ke uangnya dipake untuk membangun candi lagi jadi nanti makin banyak yang menyembah candi, seperti itu kalau yai tain menjaga jarak tapi mengarahkan kepada santri santri" Selain kiai yang memiliki peran besar pembina sebagai seseorang yang menemani keseharian santri juga memegang peran terhadap pengembanagan sikap multikultural pada santri.

Minahul (13 April 2019) "Dari segi keseharian dari pembina, guru, ustad, ustadzah, pengurus pasti menanamkan sikap saling menghargai atas perbedaan, memberikan penanaman sikap sikap damai, saling menolong, saling mengingatkan, sampai saling peduli sehingga terbentuklah rasa kekeluargaan di atas keragaman perbedaan. Memberikan pemahaman pada anak anak kalau selalu ada perbedaan dalam kebersamaan sehingga harus saling menghargai, mengingatkan jika ada yang salah, saling menolong jika ada yang kesulitan, ya seperti itulah kurang lebihnya"

Dominansi peranan kiai dalam sebuah lingkup pesantren membawa pengaruh pada tradisi suatu pesantren itu sendiri. seperti halnya yang terjadi di pesantren Tebuireng, KH Salahuddin Wahid atau yang masyhur dengan sebutan Gus Sholah membawa arus moderat di pesantren Tebuireng. Perumusan lima nilai dasar pesantren yang salah satunya meliputi nilai tasamuh terbentuk sejak Gus Sholah menduduki posisi pengasuh di pesnatren Tebuireng, gaya, karakter, dan pemikiran Gus Sholah kini mendominasi pesantren Tebuireng. Islam rahmatal lilalamin

\section{KESIMPULAN}

Pesantren yang bersifat majmuk dapat menjadi media implementasi nilai-nilai multikultural. Nilai-nilai multikultural di pesantren Tebuireng meliputi nilai Al-Musyawarah (demokrasi), Al-Musawah (kesetaraan), Al-Adl (Adil), Hablumminannnas (Hubungan dengan manusia), Al-Ta'aruf (saling [f2]mengenal), Al-Ta'awun (saling menolong ), Assalam (kedamaian), Al-'afw (memberi maaf), al-rahmah (kasih sayang), tasamuh (toleransi), al-ta'addudiyat (pluralisme), aI-tanawwn' (keragaman).

Bahwa implementasi nilai multikultural di pesantren Tebuireng lebih banyak diterapkan dalam bentuk teladan dan nasehat, adapun penerapan secara formal diterima santri dibangku sekolah. Hal tersebut tidak menjadi penghalang terlaksananya implementasi nilai multikultural, dengan adanya contoh teladan maka secara tidak langsung santri akan berfikir dan mengikuti hal yang dilakukan oleh tokoh dipesantrennya. Disebabkan implementasi nilai multikultural ini bertujuan membangun sikap multikultur pada santri maka contoh teladan yang telaksana di pesantren Tebuireng dapat menjadi jawaban bahwasannya dalam mendidik perilaku atau membangun karakter pada santri akan lebih berpengaruh dengan adanya teladan teladan seperti demikian bukan hanya pengajaran materi

\section{REFERENSI}

Arifin Imron, Muhammad Slamet. 2010. Kepemimpinan Kiai dalam perubahan manajemen pesantren (khusus pesantren tebuireng). Yogyakarta: CV Aditya Media

Arkunto, Suharsimi. 1993. Prosedur Penelitian suatu Pendekatan Praktis. Jakarta: Rineka Cipta.

Assegaf, Abd. Rahman. 2011. Filsafat Pendidikan Islam. Jakarta: Rajawali Press

Ata Andre, Benyamin Molan, Nugroho, dkk. 2009. Multikulturalisme: belajar hidup bersama dalam perbedaan. Jakarta: PT Indeks.

Baedowi, Ahmad. 2012. Calak Edu : Esai-Esai Pendidikan 2008-1012 (jilid 2). Jakarta: Pustaka Alvabet.

Dhofir, Zamakhsyari. 2011. Tradis Pesantren : Studi Pengembangan hidup kyai dan visinya mengenai masa depan Indonesia. Jakarta: LP3S.

Gunawan, K., \& Rante, Y. "Manajemen Konflik Atasi Dampak Masyarakat Multikultural di Indonesia". Jurnal Mitra Ekonomi dan Manajemen Bisnis, 2 (maret, 2011) 
Lexy J. Moleong. 2016. Metode Penelitain Kualitatif. Bandung: Remaja Rosdakarya.

Mahfud, Choiril. 2016. Pendidikan Multikultural. Yogyakarta: Pustaka Pelajar.

Maksum, Ali. 2015. "Model Pendidikan Toleransi di Pesantren salaf dan moderen”, jurnal pendidikan agama islam, 1 (Mei 2015).

Nazir, Moh. 2014. Metode Penelitian. Bogor: Ghalia Indonesia.

Pius, M Dahlan. 1994. Kamus Ilmiah Populer, Surabaya : Arloka

Pusat Pembina dan Pengembangan Bahasa. 1976. Kamus Umum Bahasa Indonesia, Jakarta : PT BALAI PUSTAKA,

Satori,Djama'an, Aan Komariah. 2017 Metode Penelitian Kualitatif, Bandung : Alfabeta

Saulah. 2011. Pendidikan Multikultural Didaktika Nilai nilai Kebangsaan. Malang: UIN Maliki Press.

Sugiono. 2016. Metode Penelitian Pendidikan pendekatan kualitatif, kuantitatif, dan R\&D. Bandung: Alfabeta.

Tilaar. 2009. Kekuasaan dan Pendidikan. Jakarta: Rineka Cipta

Al Quran Terjemah

Aly, Abdullah. 2011. Pendidikan Islam Multikulturalisme di Pesantren (Telaah Terhadap Kurikulum Pesantren Moderen Islam Assalam Surakarta).Yogyakarta: Pustaka Pelajar.

Hadi, Sutrisno. 1986. Metodologi Research. Yogyakarta: Yayasan Penerbit Fakultas Psikologi.

Ismail SM "Pembangunan Pesantren Tradisional: Sebuah Hipotesa Mengantisipasi Perubahan Sosial ", Dinamika Pesantren dan Madrasah, 1 (2 Juni 2002).

M. Mahrus dan M. Muklis "Konsep Multikulturalisme Prespektif Hadis : Studi Kitab Bulughul Maram”, fenomena, 1 (November 2017)

Maksum, Ali. 2015. "Model Pendidikan Toleransi di Pesantren salaf dan moderen", jurnal pendidikan agama islam, 1 (Mei 2015).

Nomor 1, Februari 2012 (www.iejme.com, diakses 3 Agustus 2013).

Tebuireng.online "lima nilai dasar pesantren Tebuireng " https://tebuireng.online/lima-nilai-dasar-pesantrentebuireng/ diakses pada 27 november 2018

Tebuireng.online "sejarah pesantren tebuireng" https:/tebuireng.online/sejarah/ diakses pada 27 november 2018

Tebuireng.online "sejarah pesantren tebuireng" https://tebuireng.online/sejarah/, diakses pada 27 november 2018

Tempo "Konflik Yang Dipicu Keragaman Budaya Indonesia" http://nasional.tempo.co/read/668047/konlikyang-dipicu-keragamaan-budaya-Indonesia, diakses pada 28 November 2018

Wawancara dengan Mudir Bidang Pesantren Lukman Hakim pada Sabtu, 30 Maret 2019

Wawancara dengan Pembina santri Tebuireng M Minahul Asna pada Sabtu , 13 April 2019

Wawancara dengan Pengurus Pesantren Tebireng Ananda Prayogi pada Sabtu, 20 April 2019

Wawancara dengan santri Pesantren Tebuireg Galih Seto P pada Sabtu, 27 April 2019 